\title{
Ending Ethnic Politics in Guinea through Eradicating Extreme Poverty and Providing Security
}

Sano Ibrahima Lamine*, Yusof-Talek, Ibrahem Narongraksakhet and Roflee Waehama

Prince of Songkla University Pattani Campus, Pattani, Thailand

\begin{abstract}
Despite implementing democratic multiparty-system in Guinea over two decades, governance has barely improved; the hope to eradicate poverty and provide security was dashed when people involved in politics for the wrong reasons. Great effort is spent on economic and social marginalisation through ethnic politics that is selective in dealing with economic empowerment. This study postulates that genuine changes are needed to address the malice that affect Guinean society. There is pressing need to expand human resource development. This requires adequate investments in various industrial activities. Failure in these would only add to the woe of Guinea and shall undermine its own security.
\end{abstract}

Keywords: Poverty; Ethnic Tensions; Governance; Change; Resources; Security

\section{Introduction}

Political independence had brought into being an immense optimism for the "young new" nations, in every domain, for achieving much better living standards across the African continent. However, dissatisfactions, frustrations and hopelessness have been the main obstacles to challenge that expectation in postcolonial Africa due, mainly, to bad governance. Despite what has just been stated above, most African politicians both in ruling parties and those in oppositions often act irresponsibly, further deteriorating the already appalling situations.

These horrendous conditions have increased the need for positive change. Having said that, there is only one way for the masses to achieve this positive change, which is to themselves to get political. They have seen politicians of the last half century as being the causes of their problems, which is simply a genuine truth. In fact, the problems in African countries are very similar in nature - that is to say similar illnesses and diseases require similar diagnoses and, apparently, similar prescriptions for treatments, remedies and preventive measures. This is why, we have decided to narrow the case down to an analysis of the Republic of Guinea-Conakry, in order to try to highlight its major dilemmas and challenges as well as to provide some suggestive solutions towards addressing its very basic needs - where everything has to be done, almost, from the scratch.

The need for the protection and satisfaction of Guineans has been dramatically increasing due to the "piling up" of workloads, which should have been dealt with many decades ago. Guineans, as a whole, are all victims of the current situation in one way or another, especially after the emergence of the so-called "globalisation", which is, in many ways, the integration of the world [1]. Das states that globalisation has got infinite potential for the growth and welfare of mankind, on the one hand; and it is nothing but an absolute evil, fully out to drive the poor countries back to their colonial days and into abject poverty, on the other hand [2]. Both the above statements about globalisation are true vis-àvis human nature - which can act greed and behave in moderation. It can be arguably stated that those who are pro-globalisation are driven by greed. It is very obviously noticeable that all industries in the developed world are protected by their respective governments through subsidies and quotas, directly or indirectly. This kind of act is a double standard, which makes the rich richer and the poor poorer - as most countries in the Third World - developing, least developed and underdeveloped - cannot afford to extend this kind of assistance. Eventually, infant industries in Third World countries die down and their markets are taken over by their giant competitors from the developed world - this is how it works and this is what "globalisation" is. Conversely, contraglobalisation is driven by moderating towards a more just, balanced global market place and society, where competitors and citizens are treated equally and protected.

It is a truth to recognise that globalisation is an inevitable scene today. In fact, as Guinea is a Third World country and one of the poorest on earth, yet one that is potentially rich because of its mineral deposits, fertile soil and water sources being in abundance. Given efficient and effective national strategies moved by a patriotic leadership, Guinea can take advantage of globalisation in terms of boosting intercommunity unity, education and for promoting both economic as well as moral uplift. That is, Guinea should go global in a moderated way and with all precautions exercised for the benefit of its citizens who have suffered enough and long deserve much better living standards. If managed well as it should be, the country's natural resources can help it eradicate its extreme poverty, improve its governance and even provide security through having win-win contracts with Multi National Companies (MNCs) - like Rio Tinto. This may turn to be a great benefit of globalisation for Guinea as it doesn't have the means to exploit its natural resources by itself. For this reason, the government should make sure that all its contracts are only win-win deals with multinational companies and counterpart governments, especially, though not exclusively, in the mining sector.

In this paper the following points are addressed: extreme poverty, its causes as well as its effects; seeking genuine change through application of different approaches; human resources versus natural resources; and security. Following these, the overall conclusions are provided in the

*Corresponding author: Sano Ibrahima Lamine, Prince of Songkla University Pattani Campus, Pattani, Thailand, Tel: +66883906814; E-mail: ibrahimalsano@gmail.com

Received March 01, 2018; Accepted March 22, 2018; Published March 29, 2018

Citation: Lamine SI, Yusof-Talek, Narongraksakhet I, Waehama R (2018) Ending Ethnic Politics in Guinea through Eradicating Extreme Poverty and Providing Security. Arts Social Sci J 9: 343. doi: 10.4172/2151-6200.1000343

Copyright: ( $2018 \mathrm{Lamine} \mathrm{SI}$, et al. This is an open-access article distributed under the terms of the Creative Commons Attribution License, which permits unrestricted use, distribution, and reproduction in any medium, provided the original author and source are credited. 
final section, relating to what was studied in this paper. In short, ending ethnic-orientated politics in Guinea can be attained by implementation of these excellent measures to eradicate extreme poverty and provide true security for the basic needs of all its citizens, which is to create the fair society of One Nation Guinea.

\section{Poverty}

Poverty is a lack of well-being and it is clearly multidimensional; "poverty is pronounced deprivation in well-being" [3]..$^{1}$ It is obviously noticeable that there is no true well-being in Guinea as a whole. In fact, the main cause of political unrest in Guinea is the presence of absolute poverty - the country has to build every needed basic infrastructure from the scratch. In such a retarded situation, it is very easy to get the deprived jobless destitutes impoverished youths to the street. Guinea lacks self-sufficiency in supply of staple food for its people even though it has abundant fertile cultivable soil; it does not have safe drinking water though it is nicknamed the "water tank" of West Africa; it suffers from an acute shortage of provision of decent health care; it lacks road infrastructure both urban and inter-urban; it has no electricity albeit it has plentiful supply of water for generating hydroelectric power; and above all it has a very poor and corrupted education system - education makes the best you can be; so no education means no future prosperity. It is small wonder why there is often political unrest in the country, because people have no confidence in the corrupted system. Given all these problems, Guinea as a country remains absolutely poor and destitute. The genesis of Guinea's extreme poverty mainly lies in a lack of willingness of the different regimes of the past to build any basic infrastructure, though it can be argued that there are also international causes. In this section, the possible international causes are ignored; only the national causes are discussed along with their effects. That is to say there is, therefore, a clear relation of causes and effects between the country's current problems and how it had been ruled so far by different governments.

\section{Causes of extreme poverty in Guinea}

Causes of extreme poverty in Guinea is rooted in the lack of basic necessities that the country as a whole should have gotten a long ago in order to have a decent standard of living for its people. The aim of this subsection is to point out the reasons; why this bad thing - extreme poverty - happened to the country in the first place. This attempt must be based on thorough impartiality of the authors in terms of its precision and concerns right from the origins to the current state of analyses. Briefly though, the fundamental causes can be stated are simply bad governance and poor leadership.

Bad governance and poor leadership: Bad governance is the failure of a ruling body of a particular sovereign country to carry out its responsibilities while at the same time taking advantage of available public resources through embezzlements and taking bribes - thereby becoming incapable of running public institutions, matters and resources; and poor leadership is the inability to get subordinates and followers carry out/complete their tasks and failure to be their immediate role model. These two phenomena are, to the authors, inseparable - poor leaders cause bad governance. In addition, there are numerous other features and concerns that encourage the very crime of bad governance. According to Mead some factors constraining the process of good governance are: ignorance; corruption; politicisation of administration; weak democratic institutions; ineffective parliament; and the absence of the rule of law. All of Mead's factors have become

'World Development Report, 2006 chronic ailments in the governance of Guinea in the past few decades and their eradication is not an easy process - the system of governance in Guinea must, therefore, be absolutely reformed from bottom up and in zero tolerance of in-discipline [4].

Bad governing is number one and, perhaps, the only cause of the absolute poverty in Guinea - all other bad practices are simply results of it; be it corruption, lawlessness, you name it. Bad governance, is the main enemy of economic prosperity and wellbeing because no investor would want to operate in an environment like that, it also affects the quality of human capital as it makes even the impermissible permissible, which is suicidal and destructive for any country. Further, it paralyses even the observing establishment and pressure groups.

"Problems of governance generally translate into poor economic performance, persistent institutional and legal obstacles, low professional and organizational capacity and widespread corruption. The institutions of the republic (National Assembly, Supreme Court, Economic and Social Council, National Council on Communications) are experiencing operational difficulties attributable to the poor economic situation in the country. All of them are limited in the exercise of their duties by a certain number of handicaps, in particular the lack of tradition, research capacity, information and new know-how." [5].

The above statement shows how bad governance and poor leadership can fail a state. It is not an exaggeration to argue that Guinea is hardly a state as its governments have been so ineffective and inefficient in providing even the very basic infrastructures and public services they ought to provide for the wellbeing of the people as well as to check the spreading corruption. A state does not necessary have to lose its national integrity or sovereignty to fail; however it would certainly be characterised so when it is unable to assume its functional responsibilities. In such an environment, the members of parliament, the judiciary system, other institutions of the republic and even pressure groups would all be, allegedly, corrupt. Hence, the decline of the economy is inevitable - the back bone of well-being thus, vanishes!

\section{Effects of extreme poverty in Guinea}

Effects of extreme poverty in Guinea can be numerous but the most frightening and worrying of all is political instability, which has further penalised the country in last few years - it keeps investors away and disastrously consume the already flattened economy. Besides, political instability has also resulted in violent demonstrations. Whenever there is a political demonstration it ends up ugly, deadly, disastrous and, most dangerously, ethnic. Clashes of different political supporters take place during most demonstrations, which cost businesses a fortune; they cost families lives; they cost the country a bad reputation; and they, generally, discourage investors. As a result, the country becomes poorer and unemployment rises.

Another dangerously harmful effect of extreme poverty in Guinea is corruption, which has become a chronic problem. According to Chetwynd corruption encompasses unilateral abuses by government officials such as personal embezzlement and nepotism, as well as abuses linking public and private actors such as bribery, extortion, influence peddling and fraud - it arises in both political and bureaucratic offices and it can be petty, grand or pure looting [6]. Petty corruption is the most relevant type of corruption to extreme poverty - since people receiving this type of bribe are clerks and low ranked police/gendarme officers - generally, blue-collar. For example, paying a police officer

Guinea: Poverty Reduction Strategy Paper, IMF Country Report No. 08/7January 2008. 
GNF 75,000 (US\$10.50) to let you drive an uninsured car or paying a customs officer GNF 500,000 (US\$70) to let your imported goods into the country without paying customs duty. In a similar way, a grand corruption takes place when projects are not worth their paid values. For instance, a road that costs US\$1,005,000 is built but its real value may just be US\$500,000 - as it does not last long enough, and in one to two years' time, it is in a worser condition than it used to be. Likewise, a looting corruption happens when payments have taken place in goods, services and projects that are never delivered. The last two types happen among top government officials/white-collars - this is how they unlawfully enrich themselves in big-level frauds, at the expense of poor citizens.

However, it can be argued that the reverse of the above claim is also true. That is, the effect of the corruption - grand and looting-is extreme poverty. One of the numerous causes of extreme poverty, in Guinea, is the generalised corruption. When one takes a serious look at the matter, s/he can easily see that looting and grand corruptions are the two main types that impoverish the nation. Those committing the corruption get healthy financial statuses. Their life style is far above the average national living standard. Though this counterargument makes sense, we maintain that the effect of extreme poverty in Guinea is mainly owing to corruption derived from the country's historical situations from its very creation, independence right to the present. It has never known prosperity; it has always been extremely poor. Therefore, we assert that another dangerous harmful effect of extreme poverty in Guinea is this historically-rooted corruption.

The results of the corruption and governance survey conducted on Guinea reveal that two third of business people believe that their winning competitors are always forced to pay bribes in their deals. Besides, about 53 percent of the respondents said they were not satisfied, despite paying such bribes. Further, 71 percent of business people think that if a government official breaks the rules, then they have no other option but to continue paying bribes. Incredibly, the corruption and governance survey estimates that annual bribes come to more than GNF 500 billion (US\$7,000,000), to the consequent detriment of the public treasury in terms of lost revenue ${ }^{3}$.

The figures below show how corruption can increase the effects of extreme poverty in Guinea. A petty corruption decreases the economy as it discourages businesses and investments and the cost of transactions increase. Less businesses and investments mean much fewer jobs which create more economic inequality. Eventually, poverty increases! (Figure 1). infrastructures that improve living standards. Ultimately, there is increasing levels of poverty (Figure 2 ).

\section{A Genuine Change}

A honest, real and sincere change is what the Republic of Guinea needs in order to rebuild itself and it has to start working on its shortcomings now rather than later - the more a change is delayed, the more difficult and expensive it becomes. Change is a very broad concept and it does not mean absolutely getting rid of all existing ways of doing things at the governance level - it simply means to be positively different. According to the Cambridge Online Dictionary change refers to becoming different - the act of becoming different, or the result of something becoming different. ${ }^{4} \mathrm{~A}$ change requires making some difference, transformation, amendment, reformation, modernization, even imitation and, of course, development.

A great organisational rationale, generally, based on improving performance and increasing employee satisfaction is vital, which creates effective employee involvement and it will deliver appreciation of the need for change and the willingness to embrace it, through a visible commitment created from senior leaders which will drive the change agenda throughout the organisation [7]. In fact, the approach of change studied in this section is that of management, which can be applicable also at a government level. Management is the control and organisation of something and it refers to a group of people responsible for controlling and organising a company; similarly, a government is a group of people who officially control a country ${ }^{5}$. There is a possibility of positive change in Guinea if the government is willing and ready to appoint honest and patriotic technocrats and experts based mainly on meritocracy; when people are given position because of their ability and not because they are a crony - especially in strategic positions. In addition, these technocrats and experts also must have a truly nationalistic mentality - neither too ethnic nor too tribal - to support the entire government in running and developing the country. They must be given enough power to carry out their duties in the best interest of the country.

Guinea needs to reform its public service workforce, as a huge number of the employees in that sector are long past their retirements or have reached their retirement, at least. They have worked their careers and continue to consume the potential careers of their unemployed children; they are outdated in terms of Information Technology and modern knowhow; and they are addicted to the old

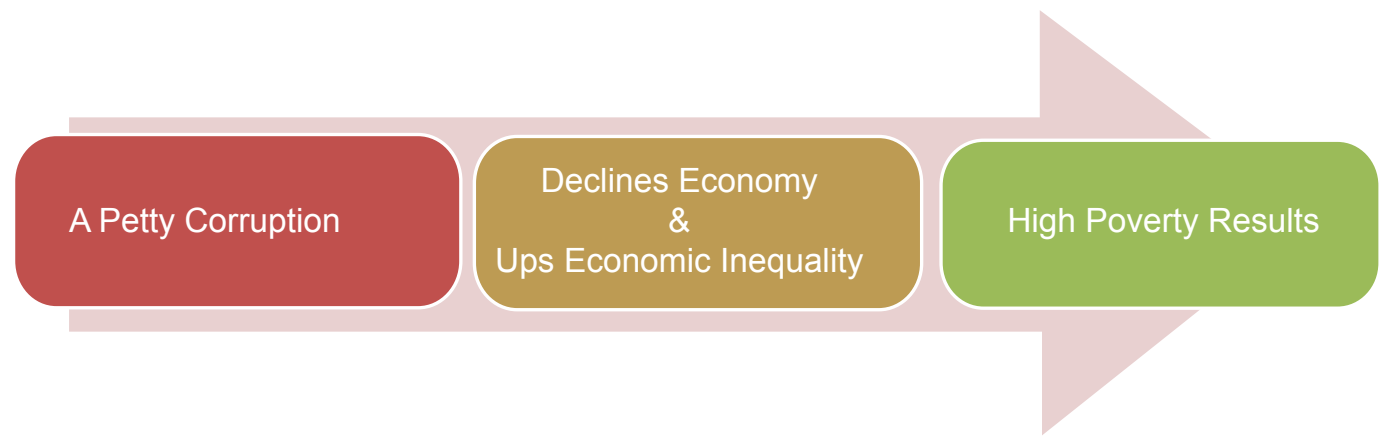

Figure 1: A Perry Corruption.

Similarly, a grand/looting corruption decreases government revenues, as a result the government has less resources to build primary

${ }^{3}$ Guinea: Poverty Reduction Strategy Paper, IMF Country Report No. 08/7January 2008.
${ }^{4}$ Cambridge Online Dictionary, http://dictionary.cambridge.org/dictionary/british/ change, accessed on 29th August 2014.

${ }^{5}$ Cambridge Online Dictionary, http://dictionary.cambridge.org/dictionary/ british/change, accessed on 29th August 2014. 


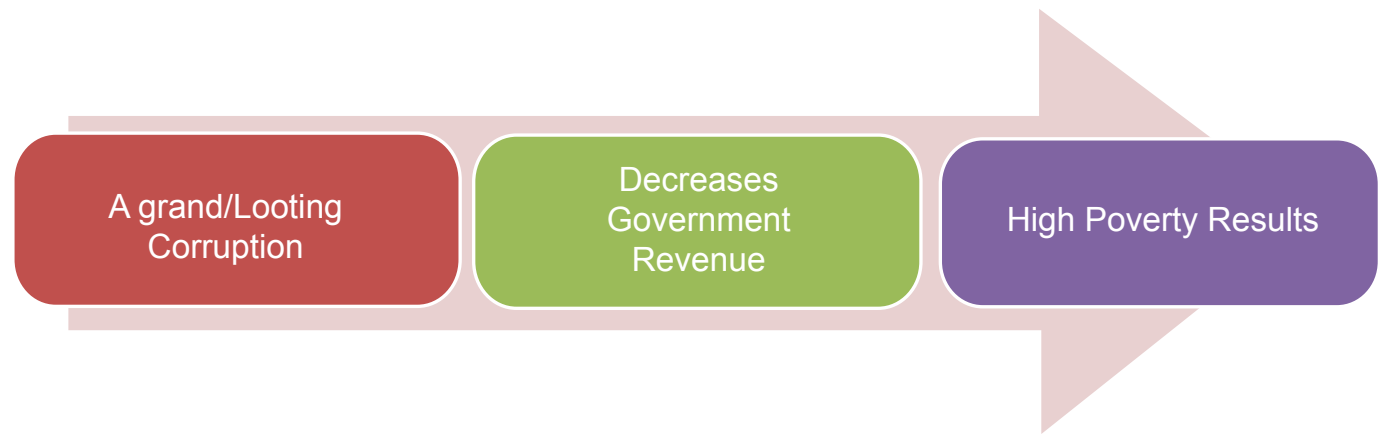

Figure 2: Looting Corruption.

style of doing things mainly through corruption. This being the case, the implementation of any change through the current ageing Guinean public workforce is difficult. That is why, we argue here that the Guinean State needs to rejuvenate (rajeunir) its workforce at all levels - to make it younger. Evidently, prevention is much easier than cure. In short, the ageing public servants are too obsessed with corruptions as we mentioned earlier, so the chance of improving the situation with them is quiet unlikely and that is why the current regime, despite its efforts, is struggling too much because it has, apparently if allegedly, ignored rejuvenating (le rajeunissement) its labour force - for the country is still being run, mostly, by the "old technocrats" of the last two régimes. Unlike the old generation, a young/rejuvenated public service would be updated in terms of Information Technology and modern know hows, they will be much more likely to accept the change with all seriousness because they have been recent victims of the old practices and they are fresh, ambitious, totally frustrated with the current situation, innocent, enthusiastic, flexible and, most importantly, desperate to develop. That is why we argue that preventing corruptions with zero tolerance among the young new public service workforce is much easier. This also means less un-employment and relatively reduced poverty as the old public servants will have their pensions as incomes and the new young entrants will also have incomes in terms of salaries. As a result, there will be relatively less crimes and troubles in our communities and in the streets.

Since Guinea has long been suffering from mismanagements, that makes it badly in need of change for the better, hopefully, in a strict zero tolerance system, especially in matters of revenue and finances. According to our research, there are two main ways of managing change, namely: behavioural and operational change.

\section{Behavioural and operational change}

Behavioural change is about making a difference in the actions and reactions of employees in an organisation through motivation; whereas operational change refers to the including or excluding of a work process and demonstrates how it can enhance the overall operation through new teachings and trainings. No government or organisation can be successful by applying operational change alone; in the long run, behavioural change is also essential to provide strategies to manage any resistance from different stakeholders, to intended change. To put it differently, changing systems and changing attitudes must be kept parallel in a government or organisation for it to succeed and to avoid resistance. There are reasons for resistance to change such as fear of failures and uncertainty. Plant asserts changes in the organisation are challenging tasks and they may encounter with resistance from the stakeholders in two forms: systemic and behavioural-where the former comes from a lack of appropriate knowledge, information, skills and managerial capacity; and the latter is based on the reaction, fears and perception of individuals or groups in the organisation [8]. Change can originate in any part of the organisation; but for it to be sustained, it requires both strategic efforts from the top and buy-ins from the bottom [9]. This statement implies that the change comes from within the country - top down and bottom up - but not from without the country-via foreign aid and international organisations.

Change must be a two way traffic system: Top-down and bottomup: Any change must be implemented both top-down and vice versa. Mere rhetoric and slogans cannot make real changes and reforms, but true actions of all stakeholders would - particularly those of the senior hierarchies. Guinea needs a nationalism awareness campaign to awaken the conscience of its people in all walks of life towards change, which is why two way traffic systems are necessary, though more emphasis should be given to the masses at the bottom.

Changing things from top-down alone is more likely to work when things are stable; unfortunately this is not the case in Guinea at the moment. Indeed, the country has seen the change of leadership - executives and senior hierarchies - at its summit since December 2010, but things have not been going as expected. That is why it can be argued that top-down approach alone cannot work in the Guinean case. Thus, things will remain the same even if a change of regime happens in the 2015 election unless a true change also takes place in bottom and middle hierarchies as well. However, the reverse is the case when there is turbulence or unstable condition - as it is sadly the case in Guinea today - in which case the bottom-up approach is also needed. When an urgent and decisive decision has to be taken, bottom-up may certainly not work. This means there are different techniques to launch change and there is no one absolute strategy which fits every situation. Berge and Dudink state that top management should look to local line leaders in order to have true commitment to change, for initiating and spreading the change [9]. Therefore, for fruitful change to happen in Guinea there may be a need to start at the grassroots of the smallest local governments/authorities then to national level/the central government and vice versa - from sectors, districts, communautés rurales de développement (CRD)/Rural development communities, sous-prefectures, communes, prefectures, administrative regions and, the last but not the least, to the ministerial departments as well as the presidency.

Reconciling the views: The question is: Are the two views irreconcilable? The answer is: No. However, there is no such thing as a small change - any type of change may still be challenging if it is not responsibly and sensibly handled. A key element for a successful 
implementation of change should be based on consultation - especially among the most concerned departments and divisions. The two concepts are reconcilable through the following:

Human approach: Executives in charge of handling a change need to be transparent in their approach. They should not be seen as dictators. The change must be compatible with the environment. It is also important to provide the proper trainings to employees, which allow them to face changes positively. There should be top-down consultations regarding sensitive problems and identifying areas which need changes. Both levels of management should plan and implement actions collectively towards a change [10].

Synergy team: To succeed in any approach to change, there is a need for sincere commitment at every level of command/management. In the case of Guinea, senior and executive public servants have to believe that changes in running the country would never be achieved on their own without teamwork and the commitments of the bottom hierarchies. Therefore, the government needs to balance their approach taking into account the lower hierarchies' views so as to find a common ground that allows state affairs to reach a consensus towards a successful change implementation.

Whistle blowing/transparency: An independent national audit institution office must be set up for whistle blowing and ensuring transparency. Its members must be elected for a non-renewable office term and they must have clean hands for eligibility; also it must have its regional offices in every administrative region and prefecture in the same manner. Its members' collaboration with any type of corruption must be dealt with heavy punishment including by jail terms and life ban from working in public services in the future running for public offices/positions. This independent body would examine and investigate the behaviour, structures and the systems in place that would allow successful whistleblowing incidents and ensure transparent public affairs.

Whistleblowing is making disclosures in the public interest by publicising specific wrongdoings taking place in the public sector; or in response to intelligence or claims suggesting that wrongdoing is probable. It occurs when whistle-blowers raise a concern about suspicions, wrongdoings or misconducts in the workplace that have public interest aspects to them - financial mismanagement, environmental damage, education weaknesses, healthcare failings, social care and so on. The ultimate purpose of whistleblowing is for the protection and reassurance of the workforce as well as for the maintenance of a healthy working culture and an efficient public sector. Whistleblowing means the existence of transparency and accountability in all government departments and national institutions.

Change comes from within the country: Although international organisations and institutions as well as the powerful wealthiest nations may have good intentions and committed ideas to eradicate poverty and make it a history; mere aid and debts cannot solve our problems - begging and relying on/receiving charities can hardly make you wealthier or better off than average working people, let alone competing with them. The consequence of foreign aid and debts is the free-rider problem - as the recipient country, Guinea in this case, had not worked for the funding and aid, consequently they become less productive, unduly relaxed and more wasteful. Concerning this poverty of epidemic proportion the former Secretary-General of the United Nations Kofi Annan [11]:

"I call on the international community at the highest level ... to adopt the target of halving the proportion of people living in extreme poverty, and so lifting more than 1 billion people out of it, by 2015".
In the same vein Gordon Brown of UK in his response to Tsunami expressed his hope that "We are one moral universe. And the shared moral sense common to us all makes us recognise our duty to others" [12].

These are certainly excellent humanitarian ideas if they could be materialised. Instead, aids and borrowings from the UN, powerful and wealthy nations and the international financial institutions made Guinea, in general, even more backward and poorer. Firstly, because of the conditionality attached to them and, secondly, you do not really value what you have not worked for - a clear free-rider problem. As designed, the sets of conditions are really meant to improve the situation of a recipient country like Guinea, but in reality things, often get worse.

The conditionality of aid usually includes giving the contracts of projects to donor countries' companies alone. So, it is primarily a way of reducing unemployment and creating business opportunities for the companies of donor countries. True donors are meant to help recipients but often they go in with little and, then, come out with more. Further, recipient countries do not value aid - usually the aid is mismanaged and/ or embezzled. In addition, loans/debts have lots of conditions attached to them; recipient countries are obliged to implement policies that may further damage their economies and political stability in the long run, for example, cutting public spending, downsizing public service employment and blind privatisation. If the truth could be told, only those hard internally sustained change and win-win trades between Guinea and the rest of the world could really improve the condition.

"Verily never will God change the condition of a people until they change it themselves (with their own souls) (Al-Qur'an 13(alRaad):11)." This Divine statement shows that change ought to come from within and not the other way round. Guineans have to be conscious of their conditions and work together for the advancement of one nation Guinea - only then would the condition of the country truly change; or else there is no way out. Moreover, there must be rule of law, however currently it is more the law of the jungle that is applied in the country, as some people act and behave as they wish all over the country - over issues such as shortages of power and water supplies; dissatisfaction with public servants; disagreements within the members of a political party/different political parties; and inadequate medical care. Sometimes both mobs and security forces get violent and be inhumane resulting in losses of lives, goods and infrastructure. In these cases, the judiciary system must be and act independent from government influences, free from the political group pressure and the opposition's manipulations, and it must be genuinely professional to hold the guilty accountable and chargeable.

On one hand, political pressure groups such as unions and the civil society as well as the opposition can be a good means of analysing government actions. When things go bad, they can disagree, criticise for the sake of decency and provide alternatives through dialogues they can do peaceful demonstrations and raise public awareness about corruption, mismanagements and other malpractices if they are not listened to - but certainly not through destructive street violence. On the other hand, the government has to respect the right for peaceful political gatherings and demonstrations - certainly no deliberate crackdowns and oppressions. The government has to listen to and have dialogue with the pressure groups and the opposition. In this way, mutual respect will exist between them for the advancement of the country, which may give way to national unity and together the people may stand to fight hard the country's "main enemy" - which is poverty - and only then would the hope for change be materialised.

A fair nationalistic parliament must also be in place in the country 
Citation: Lamine SI, Yusof-Talek, Narongraksakhet I, Waehama R (2018) Ending Ethnic Politics in Guinea through Eradicating Extreme Poverty and Providing Security. Arts Social Sci J 9: 343. doi: 10.4172/2151-6200.1000343

Page 6 of 9

for producing effective and efficient legislations. It is understood that members of parliament are elected by their different political parties, however once in parliament they should act in the best interest of the country. The parliament proves the existence of pluralism, consultation, consensus and tolerance building. A healthy strong parliament is important for providing wise legislations for the country - a parliament lacking the capacity to successfully influence government policies or influence the government cannot be considered efficient or functioning. The parliament must be able to hold the government accountable through its different committees and be able to make right laws to keep up good governance.

The next section is about extinguishing the biggest threat to the country's economy, that is political instability. Political instability diverts foreign investors from the country, it kills local businesses and, hence, serve to further impoverish the country.

\section{Human Resources versus Natural Resources}

Guinea suffers from an acute shortage of quality human resource but, at the same time, it has abundant supplies of natural resources. It is variously nicknamed a geological scandal - bauxite, iron ore, uranium, gold, diamonds, and many more; an agricultural scandal fertile soils for agriculture; and even as the water tank of West Africa - as 22 rivers including some major rivers of the sub region have their sources from the country, such as the Niger River, the Senegal River, the Gambia River and some minor ones as well as also its waterfalls and abundant rainfalls. One of the major obstacles to the country's economy is its natural resources mining sector, because of falling international commodity prices, endangering its environment as well as the risk of ending as a milking cow to multinational mining companies (Figure 3).

However, it can be argued that Guinea has got enough human resources, both within and without the country, to deal with its numerous problems and to help it be an emerging prosperous nation. That is, through the implementation of the merit system policy, by calling upon those learned Guinean expatriates spread all over the world to help the country by giving it a breath of fresh air, to run a conscious responsible government, which can lead the country and free the nation from extreme poverty. Unfortunately, we have to affirm that Guinea needs quality conscious human resources to itself re-emerge from the well it had fallen into over the ages, even though the idea of bringing in the diaspora might work. To illustrate this, the country had been bringing in its learned expatriates/intellectuals from the diaspora from

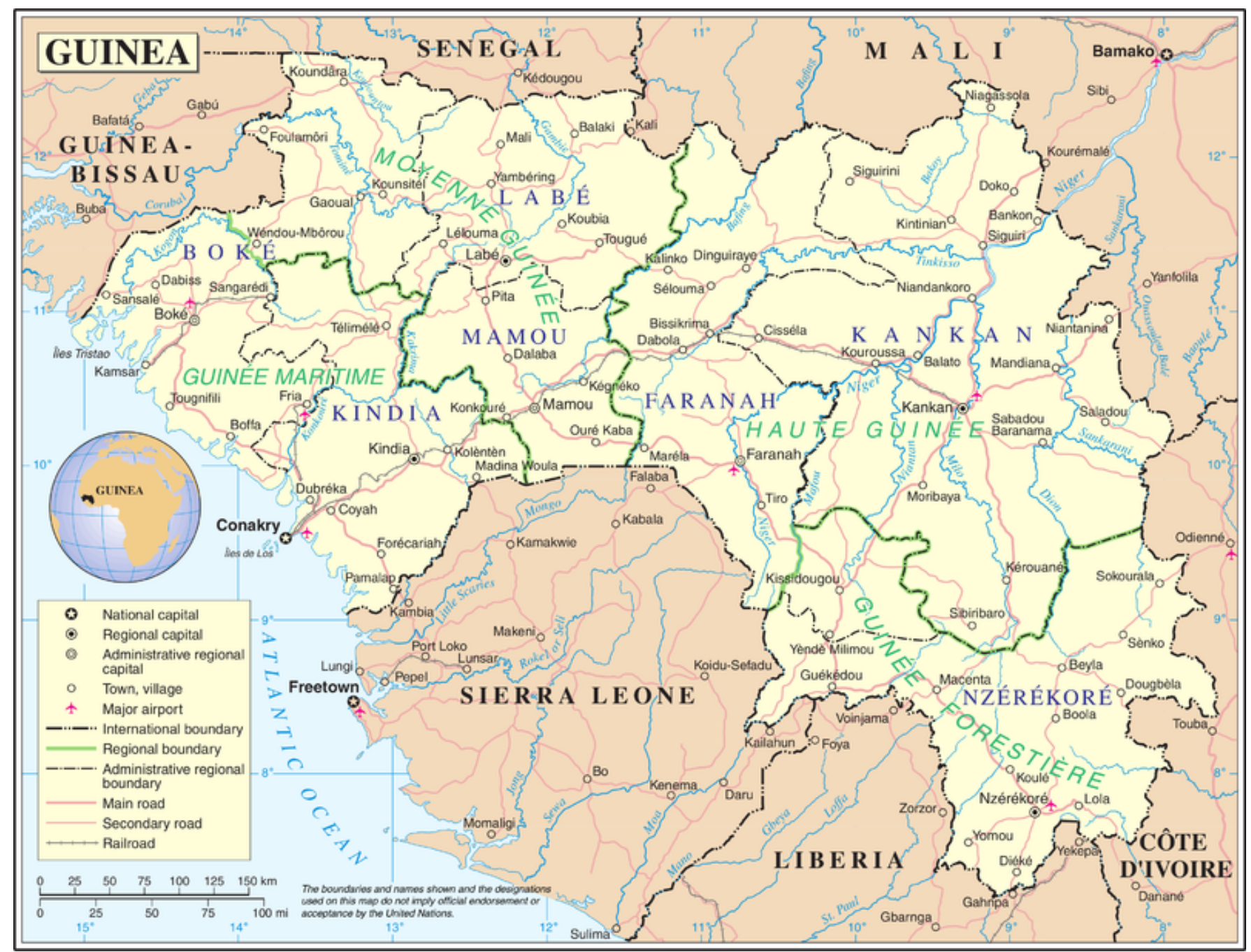

Source: https://en.wikipedia.org/wiki/Geography_of_Guinea

Figure 3: Rivers flowing from Guinea 
1985 to present but no concrete positive contributions have resulted from them and most of them gradually fall into corruption. In fact, one need not have to be a graduate from Cambridge, Oxford, Harvard or Sorbonne; a lecturer/professor at one of these said eminent universities; work at UN, other international organisations or international financial institutions; serve in high strategic positions in developed countries to actually be a quality human resource. The current Guinean government and presidency are full of ex-diaspora intellectuals but positive results have been pending and they are yet to come. One can even be national educated and still do much better for Guinea than an intellectual from Oxford. The question here is honesty, patriotism and consciousness. Hence, we emphasise that Guinea simply has to allow quality, honest, conscious human resources to emerge; it does not really matter whether they are nationally educated or are from the diaspora intellectuals.

The country should prioritise in its development plans. The prime priority should be given to education and trainings, then to agriculture and hydroelectricity infrastructure, and much less consideration should be given to the extraction mining sector and its natural resources to reduce the risk of becoming just a milking cow, in which case the people often end up not getting their fair benefits and sometimes they get nothing at all. In worst case scenario there can be ruin of the environment in general; destruction of the agricultural lands; and left with aggravated poverty.

\section{Education and training}

The role of the Guinean Government is to supply decent quality schooling for the citizens including those in deprived and remote rural areas, which is necessary for the development of the country. Most Guinean families find education unaffordable without the government's investment in schools. Most schools are in very poor condition and are overcrowded and most of the academic staff are not up to the standard, undertrained both academically and ethically. Investing in people is the best investment one can do and education makes the best one can be. Two clear-cut examples of this are South Korea and Singapore, they are among the poorest countries in terms of natural resources, yet they are at the top of the world because of their investments in their people creating human resources - and they are among the wealthiest on earth. South Korea is rated as having the best education system in the whole world. In contrast, Guinea is amongst the wealthiest nations in terms of natural resources but it is at the bottom of the rank of nations in terms of living standards, in general - one of the poorest on earth - because it lacks quality human resources capital and quality leadership. Quality education is a crucial factor for economic and social development; the education system of Guinea has always been disastrous.

The literacy rate in Guinea is merely $41 \%$ (CIA World Factbook), which is very low when compared to even emerging nations - as the country aims to be in this category. Besides, the country's education expenditures are only 2.5\% of its GDP in 2012 (CIA World Factbook). It is an essential, urgent need, for the country to intensively invest in education in order to have a quality world standard competitive education system and to maintain it so as to have a capable labour force for its intended take-off. Likewise, uneducated parents and the poor must be made aware of the benefits and opportunity costs of sending their children to schools. Education is for their betterment and uplift, in particular, and the development of the country, in general. To sum up, the country needs a high standard education system, enough school capacity, a high enrolment rate of around $90 \%$ and maintenance of the same to overcome its problems in this sector.

Training programme opportunities for updating, upgrading and maintaining skills and knowledge of the labour force in, both, the public and private sector must be available whenever the need arises - for professional development and meeting the global labour force standards, for effectiveness and efficiency sake. Competencies are only preserved through regular training.

\section{Agriculture}

Guinea is a land of fertility - it is naturally agriculture-friendly for both crop farming and livestock breeding. This fertility alone is an opportunity for the country to raise itself as a food self-sufficient and a food exporting nation. With a clear vision, Guinea can transform itself from a food shortaged, importing country to a food surplused, selfsufficient, exporting country both on a short term and long term basis. In the short run, the country should work to satisfy its national demand for food with no recourse to foreign sources as it currently does especially in its staple food, rice. In the long run, it should position itself as an exporting force for vegetables, fruits, cotton and rice. With such a vision, it can serve as a means of eradicating poverty through the continued transformation of peasant farming into commercial/ professional farming.

\section{Hydroelectricity infrastructure}

It is shockingly unbelievable that there is a country in this 21 st century which still deeply suffers from power supply shortages, despite being endowed with immense energy potentiality, for nearly six decades. Guinea is rich in water resources and has the possibility to meet its own energy demands and those of the neighbouring countries if it seriously and diligently works on some major dam building projects of high standard, which it has to. Hydro power infrastructure building requires colossal amounts of money and must be built to a very high benchmark, but once in place, electricity supply is virtually guaranteed. The water used to generate hydroelectricity can also be used for irrigation/farming and provide water supply for domestic and industrial purposes. It is clean, pollution-free, renewable and can last for many decades and beyond.

\section{Mineral resources}

The country has been extracting minerals - bauxite, aluminium and iron ore - in three major mines; namely CBG, FRIGUIA and OBK, over 40 years. Guinea has been also extracting gold and diamonds. However, these mines are cut off from the country's economy and they have not produced any major infrastructure - energy supply, roads, rails, or water supply - even at the local levels, let alone the national level. These projects should have stimulated the economy but that has not been the case; instead all Guinea has gotten is environmental destruction. So, let us wait and see what will happen for Guinea as far as the new Simandou-SIMFER Project of Rio Tinto - is concerned. As SIMFER SA is a mega project, we hope it will serve as a stimulant for the Guinean economy. That is, along with the other major infrastructure - the transGuinean railway and the deepwater port; especially when at least $80 \%$ of the jobs to be created go to Guineans; subcontracts too should go to Guinean enterprises; SIMFER SA should buy nationally; environmental protection must be enforced including by protecting water sources and replacing logged trees, reviving destroyed rain forests; and by helping the development of local school and health infrastructure, at least, around the mine and around the deep-water port [13]. Guinea may not lose out on SIMFER SA if these recommendations are considered and fully implemented. In addition, the government should be cautious in rushing further into signing any other major mining projects and should be patient at least until this SIMFER SA becomes rewarding. 
Further, the government should do all it can to make even the old existing - those in the country before SIMFER SA - mining projects get integrated into the national economy and become stimulants too. However, we still assert that the mining sector should come as the last priority in the exploitation of Guinea's total natural resources.

\section{Security}

The security of Guinea is at risk and the country needs to be rescued. As usual, Guinea had been living with the devils since its independence - a country badly divided, torn, without any easy compromise and still unable to rally all its power for the joint performance of national development. Some recent examples of this disunity is reflected in the so-called Les Accords du 03 Juillet 2013. Why involve mediation by UN? Why cannot Guineans mediate between Guineans in Guinean matters? The simple reason is the lack of confidence and trust among Guineans to handle and solve their differences by themselves; and the root cause is bad governance and the lack of meritocracy, for which all the main political leaders - both in the ruling party and opposition are partly responsible for, as they have all been involved in governance at some points in their past or present careers.

It is known to Guineans that injustice has chronically been taking place in the country for decades, which has created frustration, violence and hatred. Of course, these problems have endangered the country's security but they can all be solved if a common front is formed for the national interest. The national interest includes getting rid of discrimination, inciting hatred and violence. In a peaceful Guinea, the arsonists lose; the voice of those who plead for peace becomes stronger than that of those who plead for violence and hatred.

As far as the present authors are concerned, security is the ultimate goal in life, and it is broad. Guineans must be freed from all sorts of vulnerability. In short, security is the achievement of happiness - not absolute happiness, which is almost unachievable at the mass level but the happiness of being unchained from extreme poverty, which is the first enemy of all humanity. Guinea's true security/happiness lies in building social cohesion, political stability and economic well-being - and all further development is conditional on these points. Real development has to be founded on equity, justice and peace.

All these three are interlinked. Social cohesion is achieved when Guineans are united as a society/nation and we do no longer clash in our neighbourhoods, villages, towns and cities as members of different ethnic communities. With this in place, then political stability comes along. Political stability gives way to a stable physical environment for the government to work in for us as citizens and work to improve our lives in every walk of life. For example, the government must make sure that the people have access to an affordable quality health care system, which the country had lacked since it came into being 56 years ago. As a result, the country as whole could achieve economic development and well-being in the long run. True security means justice - when the Guineans have a fair and just system, as a nation.

Full implementation of the laws and orders for justice to prevail has to start at the very summit of the State in order to guarantee lasting security for all. The application of the laws and orders does not have to be just for thieves, armed robbers, burglars, murderers, rapists and other criminals in society; but also for all those doing dishonourable and shameful white-collar and blue-collar crimes - including briberies, embezzlements and corruptions - committed across the government and public services from top to bottom. A true justice system results in an ideal security system which, ultimately, leads to a fair society.

\section{Conclusions}

The eradication of extreme poverty and providing security are tasks of a government for its people and the failure of the Guinean State to deliver these has resulted in politicising the people unnecessarily. The causes of extreme poverty in Guinea have never been tackled sincerely despite the various efforts of its successive governments since its independence and that is why the effects of extreme poverty have been very harmful to the people and has badly damaged the reputation of the country. The main measures to achieve a genuine change in Guinea include undertaking both behavioural and operational change, the willingness of Guineans to change themselves. There is a belief that human resources are far more important than natural resources in the development of a country and in enhancing the living standards of its people. Education and training ought to be the priority in order to get the cream of human resource supply for the country. As a result, with human capital, the country can then have an excellent agricultural system and a quality socioeconomic infrastructure. Eventually, security is the end goal of socioeconomic wellbeing and it is only truly attained when its antonym - poverty - is completely eradicated.

Guinea is a poor country that possesses vast agricultural, hydropower, mineral and solar resources. Historically, the country had been an exporter of agricultural commodities, but has lately become almost a net importing nation of rice - its staple food. The causes of the country being poor lie mainly with Guineans themselves, which include their lack of ambition and vision, the lack of socio-political dialogues, widespread corruption and mismanagement of public resources. To sum up, poverty is the problem and its solution is the achievement of security for all, which only comes with awakening and the willingness to reform and put our good ideas into actions in order to develop. However the most difficult thing in reform is that; a million good ideas/ policies will certainly not succeed if Guineans just wait for the outside world to help them develop. In fact they must effectively reform from within, pure and simple without placing the blame on drastic cutbacks of external financing and aid. History has proven repeatedly that Guineans have undermined themselves and have let themselves down, as a result the outside world has lost confidence in them and has got no respect for them - the poor and beggars are hardly esteemed even locally. The present authors are sure that the Guineans can turn things around provided that they work hand in hand and hard enough to catch up with the other emerging countries and only then would the negative perception about the country turn positive. That is to say the change is us - only we can change our situations for the better and no outsider can make the Guinean lives improved if they remain dormant, even if they come with the best of plans and intentions to do so.

At present, there are no proper political parties in Guinea but only ethnic/tribal associations. Partisans mainly adhere to the parties because of the ethnicity of their leaderships. Guinean politicians selfishly and openly divide and rule by delivering mutually hateful speeches. The politicians present themselves as members of such and such ethnic group and natives of such and such region. They lack proper national political agendas. That is why all "major" political parties are ethnically based in Guinea. All the communal clashes are artificially and politically motivated. The most recent example of this was the runoff Presidential election of 2010 between RPG - Rassemblement du Peuple de Guinée (the Rally of the Guinean People) - led by a leader originally from the natural region of Upper Guinea (Faranah Region and Kankan Region) and UFDG - Union des Forces Démocratiques de Guinée (Union of Democratic Forces of Guinea) - led by a leader originally from the natural region of Middle Guinea (Labé Region 
Citation: Lamine SI, Yusof-Talek, Narongraksakhet I, Waehama R (2018) Ending Ethnic Politics in Guinea through Eradicating Extreme Poverty and Providing Security. Arts Social Sci J 9: 343. doi: 10.4172/2151-6200.1000343

Page 9 of 9

and Mamou Region). This two natural regions were not battlegrounds as both candidates were sure that they would win in their respective regions; the battlegrounds were instead the other two natural regions) - Southern Guinea (N'Zérékoré Region) and Lower Guinea (Boké Region, Kindia Region and Conakry Special Zone). Please refer to appendix A for 2010 Presidential Election of Guinea, which help demonstrate ethnic orientation politics in Guinea.

To put a stop to this, the government has to meet what the people expect from them in terms of delivery in general as discussed in this paper. As discussed in section 5 of this paper, Guinea will be a mature nation when the Guineans achieve those security levels and that will be the time when they will start following political parties, rightly, because of their manifestos and political orientations; rather than, wrongly, as now, because of their ethnic backgrounds and regions of origin. Only then would One Nation Guinea come into existence - united forever with equal opportunities for a fairer and more just nation for all its citizens.

\section{References}

1. Mrak M (2000) Globalization: Trends Challenges and Opportunities for Countries in Transition Vienna: United Nations Industrial Development Organisation.

2. Das BL (2004) An Introduction to Globalisation and Its Impact Third World Network Global Economy Series. Penang Malaysia: Third World Network.
3. Peter E (2006) "Measuring Poverty with a Changing Population" Poverty in Focus International Poverty Centre.

4. Mohamed MI (2014) How Bad Governance Affects All-the Economy Politics Social Justice Culture and Personality and How Can this Be Remedied or Replaced.

5. Guinea: Poverty Reduction Strategy Paper (2008): IMF Country Report No $08 / 7$.

6. Eric C, Frances C, Bertram S (2003) Corruption and Poverty: A Review of Recent Literature - Final Report Management Systems International.

7. Department Trade and Industry (DTI) (2005) Managing Change: Practical ways to reduce long hours and reform working practices HMSO London.

8. Plant R (1991) Managing Change and Making It Stick London: Fantona an imprint of HarperCollins Publishers

9. Dudink G, Berge Z (2006) Balancing Top-Down Bottom-Up and Peer-toPeer Approaches to Sustaining Distance Training. Turkish Online Journal of Distance Education 7: 144-152.

10. BHP Information Solutions Ltd UK (2008) "Managing Change" in Director's Brief Human Resources Management.

11. Kofi AN (2000) We the Peoples: The Role of the United Nations in the 21st Century.

12. Brown G (2005) "Brown's Marshall plan for world poor" The Guardian.

13. Valentine CA (1968) Culture and Poverty: Critique and Counter-Proposals Chicago IL: University of Chicago Press 10: 181-201. 